\title{
Pressure Immobilization Bandages Not Indicated in the Pre-hospital Management of North American Snakebites
}

\author{
Ayrn D. O'Connor • Anne-Michelle Ruha • \\ Michael Levine
}

Published online: 23 June 2011

(C) American College of Medical Toxicology 2011

To the Editor,

We would like to express our concern regarding the "2010 American Heart Association and American Red Cross Guidelines for First Aid" [1] which was published in the October 2010 issue of the journal Circulation. While overall the guidelines are well written and evidence-based, we strongly disagree with the recommendations regarding pre-hospital management of snakebite victims. Specifically, the guidelines recommending the application of a pressure immobilization bandage for both neurotoxic and nonneurotoxic American snakes. The authors cite a study by Bush and colleagues, which demonstrated that pressure immobilization is associated with delayed mortality in a porcine model of rattlesnake envenomation [2]. However, tissue injury and necrosis, rather than mortality, is the primary toxicity associated with North American rattlesnake envenomations. The application of a pressure immobilization bandage may exacerbate local tissue injury and, as demonstrated in Dr. Bush's study, may increase intracompartmental pressure, creating a surgical emergency when one did not otherwise exist. It should be noted that the very paper the guidelines cite in support of this intervention concludes "on the basis of our findings, we cannot recommend pressure immobilization widely for viper envenomation" [2].

Based on the absence of evidence for improved outcome following application of pressure immobilization devices in patients with pit viper bites and the potential risk of increased tissue injury, we advise against the use of such devices. We ask that all medical toxicologists and other experts in management of snake envenomation continue to educate and advise pre-hospital providers against the use of pressure immobilization devices in North American snakebite victims.

\section{References}

1. Markenson D, Ferguson JD, Chameides L et al (2010) Part 17: first aid: 2010 American Heart Association and American Red Cross guidelines for first aid. Circulation 122(18 Suppl 3):S934-S946

2. Bush SP, Green SM, Laack TA et al (2004) Pressure immobilization delays mortality and increases intracompartmental pressure after artificial intramuscular rattlesnake envenomation in a porcine model. Ann Emerg Med 44:599-604

A. D. O'Connor · A.-M. Ruha $(\bowtie) \cdot$ M. Levine

Department of Medical Toxicology,

Banner Good Samaritan Medical Center,

Phoenix, AZ, USA

e-mail: michelle.ruha@bannerhealth.com 